\title{
Penyesuaian Diri dan Penyesuaian Sosial Penata Rambut Laki-Laki
}

\author{
Ida Ayu Adi Wulan Virgadewi K dan Made Diah Lestari \\ Program Studi Psikologi, Fakultas Kedokteran, Universitas Udayana \\ mdlestari@unud.ac.id
}

\begin{abstract}
Abstrak
Gender dipersoalkan karena secara sosial telah melahirkan perbedaan peran, tanggung jawab, hak dan fungsi serta ruang aktivitas laki-laki dan perempuan dalam masyarakat. Gender merupakan pelabelan yang pada kenyataannya bisa dipertukarkan antara laki-laki dan perempuan. Ketika seorang laki-laki mengadopsi sifat-sifat maskulin dan seorang perempuan mengadopsi sifat feminin dapat disebut sebagai istilah gender conformity. Ciri-ciri ini tidak selamanya tetap, tetapi dapat berubah yang artinya tidak semua laki-laki atau perempuan memiliki ciri-ciri seperti itu. Ciri-ciri tersebut bisa saja saling dipertukarkan, bisa jadi ada seorang perempuan yang kuat dan rasional, tetapi ada juga seorang laki-laki yang lemah lembut dan emosional yang istilah ini sering disebut gender non conformity. Bekerja di salon bagi laki-laki adalah bentuk dari gender non conformity dan disinilah pekerja laki-laki harus bisa menyesuaikan dirinya. Penelitian ini bertujuan untuk menemukan bagaimana proses penyesuaian diri dan sosial pada penata rambut laki-laki yang bekerja di sebuah salon kecantikan. Metode penelitian ini menggunakan kualitatif dengan pendekatan fenomenologi. Responden penelitian berjumlah tiga orang laki-laki sebagai penata rambut di salon kecantikan. Hasil yang didapatkan dari penelitian ini yaitu pada proses penyesuaian diri dan penyesuaian sosial lebih mengarah pada pekerjaannya, bagaimana meningkatkan kemampuan dan keterampilan sehingga tidak lagi berbicara terkait pandangan masyarakat ataupun keraguan yang ada pada dirinya, namun terdapat perubahan yang dirasakan responden dari segi ekonomi, kemampuan menata rambut, keterampilan, dan juga perubahan penampilan yang berdampak pada tingkah laku responden yang merasa dirinya lebih feminin oleh karena lingkungan responden yang lebih dominan dengan perempuan.
\end{abstract}

Kata kunci: Penyesuaian diri dan penyesuaian sosial, Penata rambut, Gender.

\begin{abstract}
Gender is questioned because sociality has given birth to differences in roles, responsibilities, rights, functions and space for the activities of men and women. Gender is a labeling that in reality can be exchanged between men and women. When a man adopts masculine traits and a woman adopts feminine traits it can be termed as gender conformity. These characteristics are not always fixed, but they can be changed which means not all men or women have such characteristics. These traits may be interchangeable, there maybe a strong and rational woman, but there is also a gentle and emotional man whose term is often called gender non conformity. Working in a salon for men is a form of gender non conformity and this is where male workers must be able to adapt themselves. This study aims to discover how the process of self and social adjustment in the male hairdressers who work in a beauty salon. This research method uses qualitative with phenomenology approach. The respondents of the study were three men as hairdressers in beauty salons The results obtained from this study is within the process of self and social adjustment, respondent is more focused on their works, how to improve their skills so that they didn't doubt themselves anymore. But there is changes that respondents perceived in terms of economy, hair dressing skills, also appearance changes that impact on the behavior of respondents who feel themselves more feminime because of their environment is more feminime dominant.
\end{abstract}

Keywords: Self and Social Adjustment, Hairdresser, Gender 


\section{LATAR BELAKANG}

Perempuan dan laki-laki memiliki suatu perbedaan. Salah satu perbedaan dapat dilihat secara biologis yang disebut sebagai perbedaan secara alami, dimana perbedaan alami yang dimaksud yaitu perbedaan jenis kelamin. Menurut Fakih (1997) jenis kelamin mengacu pada pensifatan atau pembagian dua jenis kelamin manusia yang ditentukan secara biologis yaitu laki-laki dan perempuan, bersifat permanen atau tidak dapat dipertukarkan antara laki-laki dan perempuan, dibawa sejak lahir dan merupakan pemberian Tuhan. Melalui penentuan jenis kelamin secara biologis ini, maka dikatakan bahwa seseorang akan disebut berjenis kelamin laki-laki jika memiliki penis, jakun, kumis, janggut, dan memproduksi sperma. Sementara seseorang tersebut berjenis kelamin perempuan, jika mempunyai vagina dan rahim sebagai alat reproduksi, payudara dan mengalami kehamilan dan proses melahirkan.

Di sisi lain terdapat perbedaan yang dibangun oleh masyarakat sendiri yaitu perbedaan yang tidak alami. Menurut Rahayu (2011) gender merupakan perbedaan perilaku antara laki-laki dan perempuan yang dikonstruksikan secara sosial, yakni perbedaan yang bukan kodrat dan bukan ketentuan Tuhan melainkan diciptakan oleh manusia melalui proses sosial dan kultural. Beberapa budaya tradisional, perempuan ditempatkan pada posisi setelah laki-laki. Tatanan sosial memberi kedudukan perempuan tidak lebih penting dari laki-laki, sehingga perempuan menjadi termarginalkan bila dilihat dari berbagai macam aspek. Tidak dapat dipungkiri perempuan memang telah diberi kesempatan untuk mendapatkan pendidikan, dapat bekerja diluar rumah, bahkan dalam sistem sosial sudah berperan aktif, tetapi kenyataannya perempuan masih dianggap lebih rendah dari laki-laki. Pada posisi inilah terjadi bias gender dalam masyarakat (Fakih, 1997).

Dalam setiap budaya, gender seringkali diasosiasikan dengan hal-hal penting lain, termasuk peran, tingkah laku, kesenangan dan atribut-atribut lain yang diasumsikan sebagai khas laki-laki atau perempuan (Baron dan Byrne, 1974). Dengan demikian, peran gender mengarah pada peran sebagai laki-laki atau perempuan, dalam arti melekatnya atribusi sosial karena jenis kelamin seseorang. Jadi, peran gender merupakan peran yang diharapkan untuk ditampilkan seseorang sesuai dengan jenis kelaminnya, yaitu laki-laki atau perempuan dalam suatu budaya tertentu (Strong \& De Vault, 1989). Beberapa kecenderungan di masyarakat dan keluarga yang menyebabkan terjadinya perbedaan gender adalah memposisikan peran anak laki-laki dan anak perempuan yang berbeda, baik dalam status, peran yang melekat ataupun hak-hak yang sebenarnya merupakan hak universal. Biasanya seseorang mengatakan bahwa anak laki-laki identik dengan permainan berupa mobil-mobilan sedangkan perempuan identik dengan permainan berupa boneka.

Gender dipersoalkan karena secara sosial telah melahirkan perbedaan peran, tanggung jawab, hak dan fungsi serta ruang aktivitas laki-laki dan perempuan dalam masyarakat. Menurut Taylor, Peplau, dan Sears (2009) gender adalah salah satu kategori dasar dalam kehidupan sosial. Proses pelabelan orang, benda dan aktivitas sebagai maskulin dan feminin. Perbedaan gender sesungguhnya tidak menjadi masalah apabila tidak ada pemberitaan yang menjadikan perempuan sebagai objek yang dieksploitasi.

Seperti yang digambarkan diatas bahwa gender merupakan pelabelan yang diawali dengan proses persepsi terhadap objek mengenai berbagai macam ciri dan sifat-sifat personal yang melekat pada sekelompok orang. Maka peran gender merupakan hasil pelabelan yang akhirnya menjadi harapan sosial, dan sangat sulit melakukan perubahan konsep karena sudah menjadi stereotipe. Kontruksi ini tidak lagi membedakan laki-laki dan perempuan atas perbedaan seks yang dimiliki, dasar sosialisasi ini secara kuat telah membentuk ideologi gender, melalui kontruksi sosial misalnya perempuan dikenal memiliki sifat lemah lembut, cantik, emosional dan keibuan, kualitas ini dikenal dengan istilah feminin. Sementara laki-laki dianggap kuat, rasional, perkasa, dan jantan dimana kualitas ini dikenal dengan kualitas maskulin (Fakih, 1997).

Laki-laki umumnya dinilai lebih tinggi dibandingkan perempuan dalam hal-hal yang berhubungan dengan kompetensi dan keahlian seperti kepemimpinan, objektivitas, dan independensi. Di sisi lain, wanita biasanya dinilai lebih tinggi dalam hal-hal yang berhubungan dengan kehangatan dan ekspresi seperti kelembutan dan kepekaan terhadap perasaan orang lain (Deaux \& LaFrance dalam Taylor, dkk, 2009). Jika dilihat dari segi pendidikan perempuan dan lakilaki memiliki hak, kesempatan, dan kewajiban yang sama untuk mendapatkan pendidikan. Prestasi perempuan dalam dunia pendidikan masih dipandang rendah dibandingkan dengan kaum laki-laki. Hal itu menjadikan kaum perempuan belum memiliki ruang dalam menyalurkan aspirasi-aspirasinya karena keterbatasan akses. Sebagian masyarakat juga masih berasumsi bahwa secara alamiah laki-laki diciptakan dengan kelebihan-kelebihan yang tidak dimiliki oleh kaum perempuan.

Menurut Maccoby dan Jacklin (1974) laki-laki diindikasikan memiliki kemampuan yang lebih baik dalam bidang matematika atau tugas-tugas yang membutuhkan pemikiran, sementara perempuan lebih baik dalam tugas-tugas yang berkaitan dengan pemahaman verbal. Hingga pada akhirnya orang menyebut laki-laki lebih sering menggunakan akal dan pikirannya, sementara perempuan menggunakan rasa afeksinya. Beberapa meta analisis mengulas lebih dari seratus studi agresi. Secara umum pria lebih agresif dibandingkan perempuan dalam hal agresi fisik. Perbedaan jenis kelamin ini lebih besar dalam setting alamiah misalnya memukul dan menendang dalam permainan dibandingkan dalam setting laboratorium misalnya memukul boneka di ruang riset (Taylor, dkk, 2009).

Sistrunk dan McDavid (dalam Taylor, dkk, 2009) menyatakan bahwa perbedaan jenis kelamin dalam hal ini lebih berpengaruh terhadap gender typing dibandingkan dengan disposisi umum perempuan untuk patuh. Pada umumnya individu cenderung lebih patuh jika kekurangan informasi tentang topik atau jika topik itu dianggap tidak penting. Jadi, perempuan cenderung menurut pada tugas yang secara tradisional dianggap feminin, sehingga memunculkan anggapan bahwa individu yang memiliki karakteristik yang 
murni sesuai dengan gender disebut dengan gender typing. Adapun contoh dari gender typing yaitu ketika berbicara terkait dengan sebuah permainan berupa boneka atau pakaian yang berwarna merah muda selalu identik dengan perempuan, sedangkan laki-laki identik dengan permainan mobil-mobilan dan pakaian berwarna biru.

Pada sekitar tahun 2000-an terjadi pergeseran terkait pemisahan sifat aktivitas dan peran maskulin serta feminin. Tidak sedikit laki-laki yang memiliki sifat feminin demikian juga dengan perempuan yang memiliki sifat maskulin. Ada perempuan yang bekerja sebagai sopir, kuli, pelaut, calo, direktur, pengacara dan ada pula laki-laki yang bekerja sebagai perancang, tata rias, salon, penari dan lain-lain (Qomariyah \& Widyarini, 2006). Responden pada penelitian ini yaitu seorang laki-laki yang bekerja di bidang kecantikan sebagai penata rambut. Pekerjaan sebagai penata rambut di salon kecantikan merupakan pekerjaan yang pada umumnya dikerjakan oleh perempuan, maka muncul sebuah pandangan yang menyatakan bahwa seorang laki-laki yang bekerja di sebuah salon kecantikan merupakan bias gender karena pekerjaan sebagai penata rambut merupakan bentuk usaha yang berhubungan dengan perawatan kosmetika, wajah, dan cara mengatur dan memperbaiki tatanan rambut yang diatur sedemikian rupa menjadi lebih baik, hal tersebut berkaitan tentang keindahan yang biasa dilakukan seorang perempuan (Rostamailis, dkk, 2008).

Terdapat perbedaan jika laki-laki bekerja di sebuah salon yang merupakan salon khusus kaum laki-laki, tidak hanya memangkas rambut atau menata rambut, namun juga mencukur rambut di muka seperti kumis dan jenggot. Selain itu, juga terdapat banyak salon khusus laki-laki yang menyediakan produk dan perawatan kesehatan rambut seperti masker rambut. Hal tersebut menjadi berbeda ketika pada salon kecantikan penata rambut dilakukan oleh perempuan, begitu juga sebaliknya dengan salon pemangkasan rambut dilakukan oleh laki-laki (Rostamailis, dkk, 2008). Ketika seorang laki-laki mengadopsi sifat-sifat maskulin dan seorang perempuan mengadopsi sifat feminin dapat disebut sebagai istilah gender conformity. Ciri-ciri ini tidak selamanya tetap, tetapi dapat berubah yang artinya tidak semua laki-laki atau perempuan memiliki ciri-ciri seperti itu. Perilaku gender adalah perilaku yang tercipta melalui proses pembelajaran, bukan semata-mata berasal dari pemberian (kodrat) Tuhan yang tidak dapat dipengaruhi oleh manusia (Fakih, 1997).

Ciri-ciri yang disebut sebagai istilah gender conformity tersebut, bisa saja saling dipertukarkan. Bisa jadi ada seorang perempuan yang kuat dan rasional, tetapi ada juga seorang laki-laki yang lemah lembut dan emosional yang istilah ini sering disebut gender non conformity. Bekerja di salon bagi laki-laki adalah bentuk dari gender non conformity dan disinilah pekerja laki-laki harus bisa menyesuaikan dirinya. Penyesuaian diri merupakan proses bagaimana individu mencapai keseimbangan diri dalam memenuhi kebutuhan sesuai dengan lingkungan. Penyesuaian yang sempurna terjadi jika manusia atau individu selalu dalam keadaan seimbang antara dirinya dengan lingkungannya dimana tidak ada lagi kebutuhan yang tidak terpenuhi dan semua fungsi individu berjalan normal. Penyesuaian ini sebagai suatu proses kearah hubungan yang harmonis antara tuntutan internal dan eksternal. Dalam proses penyesuaian diri dapat saja muncul konflik, tekanan dan frustrasi dimana individu didorong meneliti berbagai kemungkinan perilaku untuk membebaskan diri dari ketegangan (Sunarto \& Hartono, 2013).

Menurut Atwater (1983) pada dasarnya penyesuaian diri memiliki dua aspek yaitu penyesuaian pribadi dan penyesuaian sosial. Penyesuaian pribadi adalah kemampuan individu untuk menerima diri sendiri sehingga tercapai hubungan yang harmonis antara diri dan lingkungan sekitar. Individu sepenuhnya sadar akan diri, menyadari kekurangan dan kelebihan, serta mampu berperilaku sesuai dengan kondisi diri dan penyesuaian sosial terjadi dalam lingkup hubungan sosial tempat individu hidup dan berinteraksi dengan individu lain. Hubungan sosial mencakup hubungan dengan masyarakat di sekitar tempat tinggal, keluarga, sekolah, teman atau masyarakat luas. Agar individu dapat melakukan penyesuaian sosial, individu harus mematuhi norma-norma dan peraturan sosial di masyarakat.

Penyesuaian diri pribadi mengandung elemen perubahan dan diri sendiri yang meliputi penyesuaian jenis kerja setiap harinya sedangkan penyesuaian diri sosial mengandung perubahan yang meliputi penyesuaian dengan teman sekerjanya, pimpinan, penyesuaian dengan lingkungan tempat individu bekerja, serta penyesuaian dengan peraturan serta batasan yang berlaku selama waktu bekerja. Individu dikatakan berhasil dalam melakukan penyesuaian diri apabila individu dapat memenuhi kebutuhannya dengan cara-cara yang wajar dan dapat diterima oleh lingkungan tanpa merugikan atau mengganggu lingkungannya (Atwater, 1983).

Menurut Gunarsa \& Gunarsa (2004) penyesuaian diri merupakan faktor yang penting dalam kehidupan manusia, sehingga penyesuaian diri dalam hidup harus dilakukan supaya terjadi keseimbangan dan tidak ada tekanan yang dapat mengganggu suatu dimensi kehidupan. Laki-laki yang bekerja di salon membutuhkan penyesuaian diri terkait dengan stigma yang berkembang di masyarakat. Dalam konsep gender, non conformity lebih ditekankan pada laki-laki dibandingkan perempuan contoh sederhananya jika perempuan memakai pakaian yang dipakai laki-laki seperti memakai celana panjang itu terlihat wajar saja di mata orang lain. Jika laki-laki yang memakai pakaian layaknya perempuan seperti memakai pakaian yang berwarna merah muda itu akan mengubah pandangan seseorang terhadap laki-laki tersebut, karena secara tidak langsung hal ini merupakan pesan yang disampaikan sesuai dengan pandangan sosial tentang gender.

Smith \& Leaper (dalam DePaul, 2009) mengungkapkan bahwa laki-laki lebih identik dengan ciri-ciri konsep gender role yang dikenal dengan gender typicality. Ketika seorang laki-laki bekerja di salon munculnya istilah gender atypicality dan non conformity.

Peneliti mengajukan suatu pertanyaan kepada 30 laki-laki terkait tentang bagaimana pandangan responden terhadap pekerja laki-laki yang bekerja di sebuah salon kecantikan. Dari 
hasil penelitian yang dilakukan peneliti, 30 laki-laki tersebut mengatakan bahwa di dalam suatu pekerjaan yang masih halal dan legal sesuai dengan tujuan yang benar maka bekerja di sebuah salon merupakan suatu hal yang biasa saja dan sah-sah saja dilakukan. Adapula pendapat responden yang mengatakan bahwa jika seorang laki-laki yang bekerja di salon kecantikan selalu digambarkan sebagai seseorang yang lemah lembut dan memiliki kepribadian ganda. Begitu pula terdapat pandangan yang berbeda yang mengatakan bahwa laki-laki yang bekerja di salon kecantikan dikarenakan memiliki kemampuan atau kegemaran di bidang salon, sehingga laki-laki sebagai penata rambut tersebut dapat dikatakan bekerja di tempat yang bukan seharusnya. Responden bekerja demi memenuhi tuntutan ekonominya dan biasanya orang yang seperti ini menyukai suatu keindahan. Dari pernyataan inilah terlihat bahwa adanya bias gender terkait dengan pekerjaan seorang laki-laki sebagai penata rambut di sebuah salon kecantikan dan data tersebut terlihat pada tabel dibawah ini yaitu terkait dengan pandangan laki-laki terhadap pekerja laki-laki di sebuah salon kecantikan (Virgadewi, 2015)

Salah satu salon ternama hadir di kota Denpasar untuk melayani masyarakat di bidang penata rambut. Untuk dapat melayani masyarakat maka salon tersebut merekrut tenaga kerja yaitu 5 orang laki-laki dan 9 orang perempuan. Berdasarkan hasil preliminary study yang telah dilakukan ketika seseorang mulai memasuki dunia kerja hal yang paling utama dilakukan yaitu melakukan penyesuaian diri, apalagi ketika seorang laki-laki yang bekerja di ranah pekerjaan perempuan maka akan merasakan kesulitan untuk berkecimpung di lingkungan tersebut, karena pekerjaan sebagai penata rambut pada umumnya digeluti oleh kaum perempuan. Mayoritas pekerja laki-laki di salon tersebut tidak memiliki dasar keterampilan di bidang salon, sehingga pekerja laki-laki tersebut berusaha mempelajari tentang penata rambut saat berpindah dari pekerjaan yang lama. Laki-laki penata rambut tersebut menikmati pekerjaan sebagai penata rambut yang ditekuni saat ini, walaupun dari sisi keuntungan responden merasa tidak puas terhadap pekerjaannya karena tidak sesuai dengan ekspektasi yang dimana bahwa salon tersebut merupakan salah satu salon yang besar berskala nasional yang seharusnya memberikan keuntungan yang besar. Dari segi dukungan keluarga yang pada awalnya tidak mendukung responden untuk bekerja di salon kecantikan yang merupakan profesi perempuan, tetapi dapat dilihat dalam jangka waktu keluarga pun dapat menerima apa yang menjadi keputusannya (Virgadewi, 2015).

“....awalnya keluarga tidak mendukung bekerja di salon, kok bisa kesana. Padahal basisnya bukan di bidang salon tetapi di otomotif tetapi lama-kelamaan keluarga jadi terbiasa dengan pekerjaan saya" (Surya dalam Virgadewi, 2015) .

Dari berbagai penjelasan tersebut, peneliti menganggap penelitian ini menjadi penting ketika seorang penata rambut laki-laki yang atypicality gender dan non conformity gender dikatakan sebagai bias gender, yang dimana pekerjaan tersebut merupakan ranah pekerjaan perempuan, sehingga memerlukan adanya penyesuaian diri dan penyesuaian sosial. Maka peneliti tertarik untuk mendalami permasalahan ini yaitu tentang penyesuaian diri dan penyesuaian sosial penata rambut lakilaki.

\section{METODE PENELITIAN}

\section{Pendekatan Penelitian}

Penelitian ini dilakukan dengan menggunakan metode kualitatif fenomenologi, yang menekankan pada penyesuaian diri dan penyesuaian sosial penata rambut laki-laki. Unit analisis yang digunakan adalah unit analisis kelompok.

\section{Kriteria Responden dan Tempat Penelitian}

Responden dalam penelitian ini adalah sebanyak tiga orang laki-laki yang berusia 18-40 tahun yang bekerja sebagai penata rambut di sebuah salon kecantikan. Proses wawancara pada ketiga responden berlangsung di bulan April 2016 hingga April 2016. Pengumpulan data dilakukan di tiga lokasi yang berbeda, lokasi pertama bertempat di salon tempat responden bekerja di salon $\mathrm{Y}$ renon, kedua adalah di salon $\mathrm{A}$ hayam wuruk dan lokasi terakhir bertempat di kediaman peneliti. Wawancara yang dilakukan untuk tiap responden adalah satu sampai tiga kali wawancara dan berlangsung dengan durasi 30 sampai 60 menit.

\section{Teknik Penggalian Data dan Analisis Data}

Penelitian ini menggunakan teknik penggalian data dengan wawancara dan observasi. Sebelum proses pengumpulan data dengan wawancara dilakukan penyusunan guideline wawancara yang akan diajukan kepada para responden. Proses wawancara didokumentasikan dengan bantuan tape recorder. Rekaman audio dilakukan untuk memudahkan proses olah data dalam bentuk verbatim yang selanjutnya akan dilakukan reduksi data, data display, dan penarikan kesimpulan.

Setelah seluruh data telah terorganisir dengan baik, maka tahap selanjutnya adalah melakukan analisa data. Teknik analisis thematic yang digunakan pertama yaitu melakukan open coding, reduksi data, proses pemilihan, pemusatan perhatian dan penyederhanaan, pengabstrakan dan transformasi data kasar yang muncul dari catatan lapangan. Setelah itu mengkaitkan pada tema-tema yang sesuai pada teori penyesuaian diri (Poerwandari, 2014).

\section{Teknik Triangulasi Data dan Isu Etik}

Dalam penelitian ini teknik triangulasi yang digunakan adalah triangulasi sumber data, metode dan waktu. Triangulasi sumber data dilakukan dengan cara mengecek data yang telah diperoleh melalui beberapa sumber, triangulasi metode dilakukan dengan menggunakan beberapa teknik pengumpulan data, dalam penelitian kualitatif ini menggunakan wawancara dan observasi dan triangulasi waktu dilakukan dengan cara pengecekan wawancara dan observasi dalam waktu dan situasi yang berbeda. Dalam penelitian ini, digunakan informed consent yang bersifat resmi yang disepakati oleh kedua belah pihak yaitu responden dan peneliti, untuk dapat mengantisipasi terjadinya cedera sosial baik dari sisi responden penelitian maupun peneliti itu sendiri. 


\section{I.A.A.W VIRGADEWI K \& M.D LESTARI}

\section{HASIL PENELITIAN}

Setelah ditemukan pola kesamaan dan hubungan dari seluruh responden atas pertanyaan penelitian, kemudian dibuat dalam bentuk topik-topik utama yang berlaku pada seluruh individu dalam tataran kelompok penata rambut laki-laki yang bekerja di sebuah salon kecantikan. Segala hal yang dituangkan dalam bagan hasil penelitian ini merupakan fakta hasil temuan dari proses pengumpulan data yang telah dianalisis. Hasil penelitian akan dipaparkan dalam empat bagian, masingmasing memiliki pola tersendiri. Hasil pertama adalah pengambilan keputusan bekerja di salon sebagai penata rambut, penilaian terkait pekerjaan di salon, proses penyesuaian diri dan sosial, dan perubahan selama bekerja di salon. Pemutusan pemilihan pekerjaan sebagai penata rambut di salon kecantikan ini dikarenakan adanya ketertarikan setelah secara langsung berkecimpung di dunia salon dan pada dasarnya suka dengan hal-hal yang berbau kecantikan sehingga dapat dikatakan sebagai hobi. Laki-laki yang memutuskan untuk bekerja di salon kecantikan juga merasa memiliki keterampilan dan memiliki jiwa seni sehingga mengambil keputusan bekerja di sebuah salon. Selain adanya ketertarikan, hal yang mendorong penata rambut laki-laki bekerja di salon adalah karena senang dengan lingkungan dan pekerjaan yang mengasyikan karena bisa mempercantik orang lain.

Pola kedua yaitu penilaian terkait pekerjaan di salon, terdapat pandangan eksternal dan internal. Pada pandangan eksternal, yakni meliputi pandangan masyarakat dan keluarga responden, banyak yang menyatakan bahwa pandangan masyarakat dan keluarga cenderung negatif terhadap laki-laki yang bekerja di salon kecantikan dan diindentikkan memiliki kepribadian ganda, sehingga keluarga merasa tidak senang dan kaget kepada responden ketika mengetahui pekerjaan yang dijalani responden. Namun terdapat perbedaan pada pandangan internal yaitu yang mengarah pada responden sendiri yang menyatakan, bekerja di sebuah salon tidak hanya berdampak negatif tetapi memiliki nilai positifnya baik secara material maupun pengetahuan terkait keterampilan sebagai penata rambut. Jika saja ada usaha dan ketekunan dalam menjalani suatu pekerjaan maka semuanya akan berjalan sesuai keinginan. Ketika tidak ada kesesuaian antara pandangan eksternal dan internal maka kemudian akan memunculkan konflik, akan tetapi pada penelitian ini pandangan internal responden dapat mempengaruhi pandangan eksternal sehingga mampu memberikan pola penguatan berupa memberikan keyakinan dan pembuktian dari hasil kerja responden terhadap keluarga dan masyarakat yang pada awalnya memiliki pandangan negatif terhadap pekerjaan responden. Jadi responden tidak memiliki kesulitan yang berarti terhadap penilaian negatif terkait pekerjaan yang menjadi profesinya.

Hasil temuan lainnya yaitu terdapat perasaan responden selama bekerja di salon, penata rambut laki-laki yang bekerja di salon kecantikan merasa adanya rasa nyaman, mendapatkan kebebasan berekplorasi dari segi penampilan dan berkreasi. Bekerja di sebuah salon dapat diidentikan dengan orang-orang yang memiliki sifat humor yang tinggi. Tidak ada perasaan malu bekerja di salon selagi bekerja dengan benar dan tidak ada perasaan menyesal selama bekerja di salon karena pekerjaan ini memang hobinya.

Pola ketiga yang dihasilkan oleh penelitian ini adalah proses penyesuaian diri dan sosial. Proses penyesuaian diri dan sosial pada laki-laki yang bekerja di salon dimana pada penyesuaian diri sudah tidak ada kendala yang didapat, begitu pula dengan penyesuaian sosial yang awalnya terdapat pandangan atau penilaian negatif terhadap laki-laki yang bekerja di salon. Pandangan tersebut dapat diubah karena terdapat adanya pola penguatan yang diberikan responden terhadap keluarga dan masyarakat, akan tetapi terdapat kendala pada keterampilan dan pengetahuan terkait sebagai penata rambut selama bekerja di salon.

Pada pola proses penyesuaian diri dan sosial ditemukan beberapa hal di dalam penelitian ini dengan menjabarkan dalam dua bentuk, yakni terdapat konteks dan karakteristik dalam penyesuaian. Konteks dalam proses penyesuaian diri dan sosial yang ditemukan dalam penelitian ini dijabarkan dalam tiga bentuk, yakni pertama terkait penyesuaian diri terhadap pekerjaan. Responden mencoba menggali kemampuan-kemampuan khusus dalam dirinya dan kemudian dikembangkan sehingga dapat membantu penyesuaian diri. Respon yang ditunjukkan meliputi rasa ingin tahu yang tinggi dengan belajar secara otodidak maupun melihat dari tutorial yang ditampilkan di sosial media, kritis terhadap hal baru dengan mengikuti seminar terkait salon, memiliki kreatifitas sehingga dapat mengembangkan keahliannya dan dapat bekerja dengan sangat baik dan selalu bersemangat.

Proses mengembangkan keahlian yakni dengan diperlukannya belajar dan pelatihan, yang sebaiknya harus dilakukan bagi pemula atau orang yang masih awam dalam dunia pekerjaan, karena pada proses tersebut banyak hal-hal yang harus dipahami sebagai karyawan salon yaitu seperti diajarkan bagaimana berhadapan langsung dengan pelanggan, mengerti perawatan rambut yang mencakup gunting, pewarnaan, dan harus mengetahui bagaimana tekstur rambut, kualitas rambut, kondisi rambut dan produk apa yang cocok digunakan untuk pelanggan. Seseorang akan menjadi sangat kreatif dan ingin menjadi lebih baik lagi dengan cara menggali pengetahuan, baik dari sosial media maupun dengan teman yang sudah lebih professional di bidangnya, selain itu responden harus memiliki ketekunan yang merupakan modal utama untuk meraih kesuksesan, dimana kesuksesan harus diperjuangkan, diusahakan dan kuncinya yaitu pada ketekunan.

Bentuk yang kedua, yakni penyesuaian diri terhadap lingkungan pekerjaan. Ketika awal responden terjun ke dunia salon, responden merasa sedikit rishi karena banyak pandangan masyarakat yang mengatakan jika seorang laki-laki bekerja di sebuah salon kecantikan dianggap memiliki kepribadian ganda, selain itu terdapat sedikit kendala terkait bertemu dengan orang baru, responden mengalami kesulitan di dalam memulai suatu interaksi dikarenakan responden termasuk tipikal orang yang tidak bisa memulai lebih dulu. Bentuk ketiga yakni, Penyesuaian diri terhadap pola komunikasi di dalam berinteraksi. Pada tahap interaksi, responden merasa di dalam berinteraksi dengan pelanggan 
biasa saja karena responden merupakan individu yang mudah akrab dan tidak ada kata malu maupun canggung saat berhadapan dengan pelanggan. Sebagai pekerja harus memiliki sifat yang ramah dan professional di dalam pekerjaannya, adapun kendala yang dirasakan yaitu pada sesama pegawai dimana karena terdapat berbagai macam karakter individu yang akan membuat suatu perbedaan pendapat di dalam berkomunikasi.

Pada karakteristik penyesuaian terdapat dua bentuk, yakni penyesuaian diri dan penyesuaian sosial. Pada penyesuaian diri yang ditemukan pada penelitian ini terdapat penyesuaian diri positif yang meliputi penyesuaian diri pada pekerjaan tahap coba-coba, pengalaman, penjelajahan pekerjaan dan penyesuaian dengan cara bercerita, sedangkan penyesuaian diri negatif meliputi reaksi bertahan. Adanya usaha individu untuk menutupi kesalahan yang diperbuat dan mempertahankan dirinya dengan menyalahkan pelanggan atas kesalahannya. Pada penyesuaian sosial, ditemukan terdapat penyesuaian sosial yang ditunjukkan dalam tiga bentuk yaitu yang pertama relasi ditempat kerja. Responden mampu menciptakan relasi di tempat kerjanya sehingga memiliki sahabat yang bisa diajak bercerita dan juga bertukar pendapat terkait pekerjaan maupun kehidupan sehari-harinya. Bentuk kedua sikap tolong menolong, terdapat sikap sosial dan kepekaan yang dimiliki responden terhadap masalah dan kesulitan orang lain disekitarnya. Responden akan menolong sesuai dengan kemampuan yang dimilikinya dan bentuk ketiga yaitu aturan di tempat kerja, adanya sikap pelanggaran yang responden lakukan di dalam peraturan pekerjaan yang terkait dengan kedisiplinan seperti terlambat masuk kerja, masalah absen dan juga kesalahan dalam memakai seragam.

Pola keempat yang didapat adalah perubahan selama bekerja di salon. Proses penyesuaian yang dilakukan responden selama bekerja di salon, terdapat perubahan yang dialami yaitu pada perubahan dari segi ekonomi, kemampuan menata rambut, keterampilan dan juga perubahan penampilan yang berdampak pada perilaku responden yang merasa dirinya lebih feminin yang disebabkan karena lingkungan responden yang lebih dominan dengan perempuan. Sebelum terjun ke pekerjaan, responden harus melalui sistem pelatihan sebagai penata rambut, sehingga responden dapat memulai suatu pekerjaan barunya. Suatu hal yang baru akan terus berkembang seiring berjalannya waktu sehingga responden mulai mengikuti kegiatan berupa seminar-seminar yang berkaitan dengan dunia salon dan dengan mengikuti berbagai pembelajaran, maka responden akan memiiki pengetahuan yang lebih baik lagi. Ketika responden telah memiliki kemampuan menata rambut atau keterampilan dalam bidang salon dan banyak dikenal pelanggan maka ekonomi pun mulai berkembang. Perubahan penghasilan yang didapatkan responden sudah sangat mencukupi untuk memenuhi semua kebutuhannya.

\section{PEMBAHASAN DAN KESIMPULAN}

Berdasarkan hasil penelitian, pembahasan akan disampaikan dalam 4 topik utama, yaitu pengambilan keputusan bekerja di salon sebagai penata rambut, penilaian terkait pekerjaan di salon, proses penyesuaian diri dan penyesuaian sosial dan perubahan selama bekerja di salon.

\section{Pengambilan Keputusan Bekerja di Salon Sebagai Penata Rambut}

Pengambilan keputusan pada penelitian ini ditemukan bahwa pengambilan keputusan bekerja di salon sebagai penata rambut laki-laki itu sangat dipengaruhi oleh ketertarikannya terhadap dunia kecantikan. Sejalan dengan penelitian Zamroni (2016) menyatakan bahwa pengambilan keputusan karir merupakan proses yang bisa menjadi penentu masa depan seseorang. Individu memiliki kemandirian, membuat pilihan pekerjaan yang sesuai dengan minat. Ketertarikan itu menunjukan seseorang pada minat yang dimilikinya.

Hobi pun termasuk ke dalam minat, selain minat hal yang berperan adalah kemampuan dan keterampilan atau bakat. Responden dalam penelitian ini menunjukan bahwa mereka memiliki jiwa seni dan keterampilan atau bakat, itulah yang mendukung responden dalam pengambilan keputusan bekerja di salon. Adapun prediksi ke depan yang ingin dilakukan oleh responden yaitu terkait ekonomi dimana responden ingin mengembangkan keterampilannya dan membuka usaha sendiri di bidang kecantikan. Sejalan dengan teori yang diungkapkan Suharnan (2005), pengambilan keputusan adalah proses memilih atau menentukan berbagai kemungkinan di antara situasi-situasi yang meminta seseorang harus membuat prediksi kedepan, memilih salah satu di antara dua pilihan atau lebih, membuat perkiraan mengenai frekuensi yang akan terjadi. Salah satu fungsi berpikir adalah menetapkan keputusan. Keputusan yang diambil seseorang beraneka ragam, tanda-tanda pada umumnya adalah keputusan merupakan hasil berpikir, hasil usaha intelektual, keputusan selalu melibatkan pilihan dari berbagai alternatif, keputusan selalu melibatkan tindakan nyata, walaupun pelaksanaannya dapat ditangguhkan atau dilupakan.

Berdasarkan hasil penelitian di atas, pengambilan keputusan dalam pekerjaan merupakan faktor yang penting, dapat dikatakan demikian karena tujuan seseorang dalam mengembangkan potensi seseorang secara optimum harus diawali dengan pengambilan keputusan secara tepat, berkaitan dengan arah peminatan yang mana yang sesuai dengan kemampuan responden. Selain itu, responden mampu menyusun strategi yang baik dalam meraih kesuksesan pada setiap arah peminatan yang telah ditentukan. Penentuan pilihan tidak hanya selesai ketika responden sudah mampu memilih pilihan tetapi juga diwujudkan dalam bentuk tanggung jawab terhadap pilihan yang telah diambil oleh responden sehingga mendapatkan manfaat maksimal dari pilihannya tersebut.

\section{Penilaian Terkait Pekerjaan di Salon}

Setiap Orang Memiliki Perbedaan sudut pandang terkait pekerjaan yang dijalani, banyak yang menyatakan bahwa pandangan masyarakat dan keluarga cenderung negatif terhadap laki-laki yang bekerja di salon kecantikan dan diidentikan memiliki kepribadian ganda, dimana terdapat dua atau lebih kepribadian yang berbeda di dalam satu tubuh. Menurut American Psychological Association (2015) individu 
yang memiliki penampilan, sikap, atau identitas gender yang tidak sesuai dengan jenis kelamin yang didapatkan ketika lahir dapat dikatakan gender non-conformity, sehingga sesuai dengan pandangan masyarakat dan keluarga yang cenderung berpandangan negatif terhadap pekerjaan yang tidak sesuai dengan gender atau jenis kelamin.

Pekerjaan yang dikatakan tidak sesuai dengan peran gender inilah, sehingga memunculkan respon dari keluarga responden, dimana keluarga responden merasa kaget dan kurang menerima keputusan yang diambil responden untuk bekerja di sebuah salon kecantikan, tetapi pandangan tersebut diubah oleh responden dengan memberikan pola penguatan yaitu dengan meyakinkan keluarga bahwa bekerja di salon tidak selalu berdampak negatif, ada dampak positifnya dapat dilihat dari segi keuntungan dan juga keterampilan. Bekerja di salon juga bisa membuat individu menjadi sukses jika bekerja dengan sungguh-sungguh dan yang terpenting memiliki kepercayaan diri terkait keputusan pekerjaan yang diambil.

Kepercayaan diri pada dasarnya adalah kemampuan dasar untuk dapat menentukan arah dan tujuan hidupnya. Gufron dan Risnawati (2011) menyatakan bahwa orang yang memiliki kepercayaan diri positif memiliki aspek keyakinan kemampuan diri, optimis, objektif, bertanggung jawab, rasional dan realistis, sehingga responden sudah tidak memiliki kendala yang didapat saat mengambil keputusan bekerja di salon kecantikan sebagai penata rambut. Sejalan dengan penelitian Asiah (2007) yang mengatakan bahwa secara sosial responden merasa tidak ada masalah dengan penyesuaian diri dengan profesi yang terkadang dianggap kurang layak oleh masyarakat. Responden justru tidak mengisolasikan diri dalam kehidupan pribadinya, sebaliknya responden seakan-akan ingin memperkenalkan bahwa selama pekerjaan yang ditekuni masih halal, maka wajar saja untuk ditekuni.

Pada penelitian ini responden memiliki penilaian internal yang lebih kuat daripada eksternalnya, sehingga pekerjaan yang dijalaninya menjadi lebih berarti ketika mendapat dukungan dari keluarga apalagi responden sudah memiliki keterampilan atau bakat yang baik di bidang menata rambut, sehingga responden mampu menyesuaikan diri dengan lingkungannya dengan cara yang baik dan responden juga dapat menyelesaikan kesulitan-kesulitan terkait pandangan tersebut. Sejalan dengan teori Schneiders (1964) juga mengemukakan bahwa orang yang dapat menyesuaikan diri dengan baik adalah orang dengan keterbatasan yang ada pada dirinya, belajar untuk bereaksi terhadap dirinya dan lingkungan dengan cara yang matang bermanfaat, efisien, dan memuaskan, serta dapat menyelesaikan konflik, frustrasi, maupun kesulitankesulitan pribadi dan sosial tanpa mengalami gangguan tingkah laku.

\section{Proses Penyesuaian Diri dan Sosial}

Pada konteks dalam penyesuaian diri dan sosial ini ditemukan beberapa hal dalam penelitian ini dengan menjabarkan dalam tiga bentuk, yakni penyesuaian diri terhadap pekerjaan, penyesuaian diri terhadap lingkungan pekerjaan dan penyesuaian diri terhadap pola komunikasi di dalam berinteraksi.

Penyesuaian diri terhadap pekerjaan

Ketika seseorang mulai bekerja membutuhkan penyesuaian diri dan sosial, pada tahap ini responden memerlukan penyesuaian diri terhadap pekerjaan. Individu mencoba mengembangkan keahlian dengan menggali kemampuankemampuan khusus dalam dirinya dan kemudian dikembangkan. Sejalan dengan penelitian Wardani (2009), keahlian merupakan sesuatu minat atau bakat yang harus dimiliki oleh seseorang, dengan keahlian yang dimilikinya memungkinkan untuk dapat menjalankan dan menyelesaikan tugas-tugas secara baik dengan hasil yang maksimal. Keahlian yang dimiliki seseorang dapat diperoleh dari pendidikan formal maupun non formal yang nantinya harus terus menerus ditingkatkan. Salah satu sumber peningkatan keahlian dapat berasal dari pengalaman-pengalaman dalam bidang tertentu.

Pengalaman tersebut dapat diperoleh melalui proses yang bertahap, seperti pelaksanaan tugas-tugas, pelatihan ataupun kegiatan lainnya yang berkaitan dengan pengembangan keahlian seseorang. Respon yang ditunjukkan untuk meningkatkan keahlian, responden meliputi rasa ingin tahu yang tinggi dengan belajar secara otodidak maupun melihat dari tutorial yang ditampilkan di sosial media, kritis terhadap hal baru dengan mengikuti seminar terkait salon, memiliki kreativitas sehingga dapat mengembangkan keahliannya dan dapat bekerja dengan sangat baik dan selalu bersemangat.

Setiap tempat kerja yang memiliki standar yang tinggi akan membutuhkan tenaga kerja yang memiliki tingkat kamampuan yang lebih, sehingga diperlukanya keahlian-keahlian yang khusus untuk menunjang berkembangnya sebuah perusahaan. Sejalan dengan penelitian Girsang (2014) menyatakan bahwa dalam membuka usaha salon kecantikan sangat dibutuhkan karyawan yang terampil dan tekun untuk memberikan pelayanan yang baik kepada konsumen, sebab telah bermunculan salon-salon dengan kualitas tinggi sehingga kualitas produk dan jasa harus tetap dijaga. Karyawan diharuskan memiliki kualitas dan kemampuan yang lebih baik lagi dalam rangka mengimbangi salon-salon kecantikan yang berkembang pesat saat ini, sehingga responden penelitian ini yang merupakan karyawan salon harus mampu meningkatkan keterampilan dan kemampuannya dengan mengikuti pelatihan seperti seminar-seminar. Selain untuk meningkatkan mutu perusahaan, responden pun memiliki cita-cita untuk membuka usaha salon sendiri sehingga upaya yang dilakukan menjadi sebuah pengalaman dan tentunya menjadi bermanfaat untuk kedepannya bagi responden.

Penyesuaian diri terhadap pekerjaan yang telah dialami oleh responden yang bekerja di salon kecantikan sebagai penata rambut laki-laki dijabarkan dalam suatu proses yaitu belajar, pelatihan dan ketekunan.

\section{Belajar dan pelatihan}

Ketika seseorang mulai memasuki suatu hal yang baru harus melalui suatu pembelajaran yang akan memberikan pengetahuan yang khusus, belajar dan pelatihan biasanya dilakukan bagi orang yang masih awam karena pada proses 
tersebut banyak hal-hal yang harus dipahami sebagai karyawan salon yaitu seperti diajarkan bagaimana berhadapan langsung dengan pelanggan. Oleh karena itu, pelatihan lebih menekankan pada peningkatan pengetahuan, keterampilan dan pengalaman. Sejalan dengan penelitian Rudhaliawan (2013), menyatakan bahwa pelatihan berpengaruh signifikan terhadap kemampuan, hal ini menunjukkan bahwa pelatihan akan memberikan kesempatan bagi karyawan untuk mengembangkan keahlian dan kemampuan baru dalam bekerja agar apa yang diketahui dan dikuasai saat ini maupun untuk masa mendatang dapat membantu karyawan untuk mengerti apa yang seharusnya dikerjakan dan memberikan kesempatan untuk menambah pengetahuan dan keahlian. Hal ini menunjukan bahwa pelatihan sangat bermanfaat untuk perusahaan dan karyawanya itu sendiri.

Hal ini sejalan dengan pendapat Simamora (1995) yang menjelaskan bahwa pelatihan merupakan serangkaian aktivitas yang dirancang untuk meningkatkan keahlian, pengetahuan, pengalaman ataupun perubahan sikap seseorang individu atau kelompok dalam menjalankan tugasnya. Peningkatan keahlian responden adalah mengikuti serangkaian pelatihan seperti mengikuti seminar-seminar yang mengkhususkan seminar terkait penata rambut, dengan mengikuti pelatihan ini responden memiliki banyak pengalaman dan keterampilan yang bisa responden kembangkan kedepannya.

\section{Ketekunan}

Ketika seseorang sudah mulai menguasai pekerjaan yang digeluti, maka seseorang akan menginginkan menjadi lebih baik lagi dan akan menjadi sangat kreatif. Pengetahuan atau kognitif merupakan domain yang sangat penting untuk terbentuknya perilaku seseorang (Notoatmodjo 2003). Responden memiliki ketekunan yang merupakan modal utama untuk meraih kesuksesan, dimana kesuksesan harus diperjuangkan, diusahakan dan kuncinya yaitu pada ketekunan.

Sejalan dengan teori Poerwadarminta (1982) ketekunan adalah kekerasan tekat dan kesungguhan hati artinya bekerja, belajar, dan berusaha semaksimal mungkin, sehingga dengan kesungguhan hati dan tekat yang kuat bisa dijadikan sebagai teladan bagi orang lain dan memberikan hasil kepada dirinya sendiri. Seseorang yang memiliki tingkat ketekunan tinggi, akan lebih konsentrasi pada setiap pembelajaran dengan cara mencermati, merenungkan, menganalisis, kemudian memilih mana yang baik untuknya dan mana yang harus ditinggalkan. Biasanya memiliki tingkat ketekunanya tinggi sangat peka dan sensitif terhadap lingkunganya, pandai membaca situasi, mampu mengambil keputusan yang tepat, cepat namun terkesan tenang, tanpa ada unsur keterpaksaan yang artinya bahwa sesuatu yang telah dikembangkan seoptimal mungkin pada dirinya akan menghasilkan sesuatu yang baik. Hal itu merupakan satu langkah untuk menunjukkan kemampuan (potensi) yang dimiliki. Responden memiliki tingkat ketekunan yang tinggi yaitu menjadi lebih kreatif dengan mencari tahu sendiri hal-hal yang tadinya tidak responden ketahui dengan cara belajar melalui media sosial dan juga bertanya kepada ahli yang lebih berpengalaman.
Penyesuaian diri terhadap lingkungan pekerjaan

Terdapat perasaan risih ketika memulai memasuki pekerjaan yang menurut pandangan masyarakat yang mengatakan jika seorang laki-laki bekerja di sebuah salon kecantikan dianggap memiliki kepribadian ganda. Sejalan dengan teori American Psychological Association (2015) gender non-conformity merupakan individu yang memiliki penampilan, sikap, atau identitas gender yang tidak sesuai dengan jenis kelamin yang didapatkan ketika lahir. Ciri-ciri dari gender non-conformity yaitu dimana seorang perempuan memiliki kepribadian yang kuat dan rasional dan ada juga seorang laki-laki yang memiliki kepribadian lemah lembut dan emosional. Pada responden keadaan yang tidak sesuai dengan kaidahnya berupa perubahan tingkah laku dan berpenampilan seperti perempuan. Penyesuaian diri terjadi ketika kita sudah mulai mengenal lingkungan sekitar, tahu bagaimana karakter dan tingkah laku atau kepribadian seseorang di lingkungan kerja.

Sejalan dengan penelitian Yvonne (2014) mengatakan bahwa watak gigih mengacu pada sifat tidak mudah menyerah, tidak mudah putus asa dan selalu maju dalam menghadapi setiap rintangan hambatan, sedangkan sikap mudah beradaptasi mengacu pada sifat tidak mengalami kemunduran bila ditempatkan pada lingkungan yang baru, juga memiliki pribadi yang dapat menyesuaikan dengan keadaan sekitar, sehingga banyak dari responden cepat mendapat teman baru. Sikap mudah beradaptasi yang dilakukan responden yaitu dengan cara mengembangkan kemampuannya, bersikap ramah, sopan santun dan menunjukan hasil kinerja yang baik. Responden pun memiliki sifat yang mudah dalam bergaul sehingga inilah faktor yang membantu responden dalam penyesuaian diri di lingkungan kerja.

$\underline{\text { Penyesuaian diri terhadap pola komunikasi di dalam }}$ berinteraksi

Ketika seseorang dapat melakukan penyesuaian diri dengan baik, maka pada tahap interaksi dimana responden menunjukan sikap biasa saja dikarenakan responden merupakan individu yang mudah akrab dan tidak ada kata malu maupun canggung saat berhadapan dengan pelanggan. Sejalan dengan penelitian Asiah (2007) mengatakan bahwa responden merasa tidak asing dan tidak canggung, orangorang justru memberikan kepada dirinya nuansa kekeluargaan tidak ada penghinaan maupun diskriminasi.

Sebagai pekerja harus memiliki sifat yang ramah dan professional di dalam pekerjaannya dan begitu pula sebagai makhluk sosial, individu dituntut untuk mampu mengatasi segala permasalahan yang timbul sebagai hasil dari interaksi dengan lingkungan sosial dan mampu menampilkan diri sesuai dengan aturan atau norma yang berlaku. Oleh karena itu setiap individu dituntut untuk menguasai keterampilan-keterampilan sosial dan kemampuan penyesuaian diri terhadap lingkungan sekitarnya. Sejalan dengan teori Santoso (2010) interaksi sosial merupakan salah satu cara individu untuk memelihara tingkah laku sosial individu tersebut sehingga individu tetap dapat bertingkah laku sosial dengan individu lain. Interaksi sosial dapat pula meningkatkan jumlah atau kuantitas dan mutu atau kualitas dari tingkah laku sosial individu sehingga individu makin matang di dalam bertingkah laku sosial dengan individu lain di dalam situasi sosial. 


\section{I.A.A.W VIRGADEWI K \& M.D LESTARI}

Adapun kendala yang dirasakan responden pada penelitian ini, salah satunya adalah berbagai macam karakter dari sesama pegawai salon, sehingga hal ini berdampak pada perbedaan pendapat di dalam berkomunikasi. Komunikasi dalam organisasi menjadi hal penting untuk menciptakan kesamaan pemahaman atas informasi yang disampaikan satu sama lain. Sejalan dengan teori Effendy (1994) yang menyatakan bahwa komunikasi akan berhasil jika terdapat kesamaan makna atau pemahaman, apabila pesan yang disampaikan oleh komunikator sesuai dengan kerangka acuan yakni paduan pengalaman dan pengertian yang diperoleh oleh komunikan. komunikasi sangat dibutuhkan untuk meningkatkan kinerja karyawan, maka dari itu diperlukannya kemampuan dalam berkomunikasi.

Hasil penelitian Hariyanti dan Primawesri (2011) mengemukakan motivasi dan komunikasi berpengaruh positif terhadap kinerja karyawan melalui komitmen organisasi. Sejalan dengan hasil penelitian Yakub, Gunawan \& Halim (2015) yang menjelaskan bahwa kemampuan komunikasi merupakan salah satu faktor yang dominan berpengaruh terhadap kinerja karyawan ,untuk itu karyawan harus mampu berkomunikasi dengan baik dalam menempatkan diri pada situasi yang berbeda-beda dengan atasan dan rekan kerja yang sedang diajak berkomunikasi serta memberikan informasi yang jelas agar hasil pekerjaan yang diperoleh dapat maksimal.

Pada karakteristik penyesuaian terdapat dua bentuk, yakni penyesuaian diri dan penyesuaian sosial:

\section{Penyesuaian diri}

Pada penyesuaian diri yang ditemukan pada penelitian ini terdapat penyesuaian diri positif dan penyesuaian diri negatif:

Penyesuaian diri positif

\section{Penyesuaian diri pada pekerjaan tahap coba-coba}

Tahap coba-coba dalam menentukan pekerjaan yang cocok pernah dilakukan oleh responden, banyaknya pengalaman kerja yang dilakukan untuk menemukan jati diri ini membuat responden tidak menyerah untuk mencoba hal baru. Temuan dari penelitian ini sejalan dengan teori penyesuaian diri positif dimana Sunarto \& Hartono (2013) menyatakan bahwa penyesuaian dengan tahap coba-coba ini merupakan suatu tindakan yang dilakukan secara coba-coba yang dalam artian, jika menguntungkan maka akan diteruskan dan jika gagal maka tidak akan diteruskan. Jadi, proses tahap coba-coba yang dilakukan responden di dalam pekerjaannya, yaitu dengan mencoba membuka bisnis baru yang berbeda jauh dari bidang keterampilan sebelumnya. Akan tetapi bisnis tersebut tidak berjalan lancar, dikarenakan bisnis yang dijalani tidak sesuai dengan keterampilan yang dimiliki responden, sehingga responden pun kembali kepekerjaan semula yaitu bekerja di salon sebagai penata rambut, karena menurutnya pekerjaan ini lebih menguntungkan, santai dan tidak memakan waktu yang berlebih.

\section{Pengalaman}

Pengalaman yang didapat selama bekerja di salon sangatlah bermanfaat dari yang tidak mengerti jadi mengerti. Responden akan mencari terus pengalaman-pengalaman yang lainnya karena pengalaman merupakan pengetahuan yang akan mengembangkan tingkat kemampuan seseorang, sehingga tidak ada kata puas untuk mencari suatu pembelajaran dari pengalaman yang didapatkan dan semakin lama bekerja semakin tinggi tingkat kemampuan yang didapatkan. Hasil penelitian ini menunjukkan bahwa semakin berpengalaman seorang karyawan maka akan menunjang terciptanya produktivitas kerja yang optimal.

Hasil penelitian ini didukung oleh Rivai (2004) memberikan pandangan spesifik mengenai pengalaman kerja yang diidentikkan dengan masa kerja. Masa kerja yang dimaksud yaitu lama waktu seseorang menduduki jabatan pekerjaannya. Masa kerja yang lama menunjukkan pengalaman yang lebih dari seseorang dengan rekan kerja yang lain. Banyak sedikitnya pengalaman kerja dapat mempengaruhi seseorang dalam mengelola dan melaksanakan tugas kinerja dan tingkat pendapatan mereka. Didukung dengan hasil penelitian dari Sukmana (2013) bahwa pengalaman kerja dalam pekerjaan sektor formal pada umumnya dianggap dapat meningkatkan kemampuan kerja seseorang. Seseorang akan memiliki kesempatan meningkatkan pendapatan dan produktivitas dengan pengalaman yang jauh lebih lama.

Sejalan dengan teori Notoatmodjo (1997) pengalaman merupakan guru yang terbaik, dapat diartikan bahwa pengalaman merupakan sumber pengetahuan atau pengalaman itu suatu cara untuk memperoleh kebenaran pengetahuan. Oleh sebab itu pengalaman pribadi pun dapat digunakan sebagai upaya untuk memperoleh pengetahuan. Hal ini dilakukan dengan cara mengulang kembali pengalaman yang diperoleh dalam memecahkan permasalahan yang dihadapi pada masa lalu.

\section{Penjelajahan pekerjaan}

Penelitian ini menemukan bahwa sebelum terjun langsung ke dunia salon responden awalnya mencari suatu pengalaman dalam mencari pekerjaan yang cocok dengan cara mencobacoba melamar pekerjaan di restoran, pabrik, hotel, bekerja sebagai taksi dan juga melihat pekerjaan teman dimana pada akhirnya bisa bekerja di salon kecantikan walaupun dilihat dari jurusan yang dipilih tidak ada yang menjerumus kearah dunia kecantikan. Sejalan dengan teori Sunarto \& Hartono (2013) menyatakan penyesuaian dengan melakukan penjelajahan, dimana dalam situasi ini individu mencari berbagai bahan pengalaman untuk dapat menghadapi dan memecahkan masalahnya.

Responden dapat menentukan karirnya setelah melakukan eksplorasi pekerjaan yang nantinya akan mendapatkan pengalaman-pengalaman kerja dan juga dapat menemukan keterampilan atau kemampuan apa yang sepantasnya responden tekuni, karena pengalaman adalah faktor utama yang mempengaruhi pembentukan seseorang, baik dalam belajar dari pengalaman yang pernah dialaminya. Pengalaman juga dapat memunculkan potensi seseorang. Sejalan dengan penelitian Ratnaningsih (2013) menyatakan pada hakikatnya pengalaman adalah pemahaman terhadap sesuatu yang dihayati dan dengan penghayatan serta mengalami sesuatu tersebut diperoleh pengalaman, keterampilan ataupun nilai 
yang menyatu pada potensi diri. Orang yang berpengalaman dalam bekerja memiliki kemampuan kerja yang lebih baik dari orang yang baru saja memasuki dunia kerja, karena orang tersebut telah belajar dari kegiatan-kegiatan dan permasalahan yang timbul dalam kerjanya. Berkat adanya pengalaman kerja maka telah terjadi proses penambahan ilmu pengetahuan dan keterampilan serta sikap pada diri seseorang, sehingga dapat menunjang dalam mengembangkan diri dengan perubahan yang ada.

\section{Penyesuaian dengan cara bercerita}

Ketika mengalami suatu kegagalan di dalam pekerjaan, responden tidak menutupi kegagalan tersebut. Cara responden dalam menyelesaikan masalahnya dengan cara meminta pendapat atau masukan kepada orang terdekat, baik dengan sahabat maupun dengan istri responden. Tindakan yang dilakukan responden yaitu dengan cara bercerita. Sejalan dengan penelitian Yulianingsih (2012) bahwa langkah-langkah yang dilakukan oleh responden dalam menyelesaikan masalah yaitu dengan cara menyusun langkah-langkah penyelesaiannya sendiri dan ada juga meminta masukan dari orang lain, sehingga responden menjalankan saran atau masukan dari orang lain (teman atau saudara). Pada intinya responden menginginkan tempat untuk mengungkapkan isi hati dan meminta masukan tentang apa yang harus dilakukan. Hal ini sejalan dengan teori Lazarus dan Folkman (1984) yaitu dengan menggunakan strategi coping jenis exercised caution yakni individu berfikir dan mempertimbangkan beberapa alternatif pemecahan masalah yang tersedia, meminta pendapat orang lain, berhati-hati dalam memutuskan masalah serta mengevaluasi strategi yang pernah dilakukan sebelumnya. Responden pada penelitian ini berusaha memilih tindakan tersebut agar dapat menyelesaikan permasalahan. Menurut Piaget (dalam Davidoff, 1988) menyatakan kemampuan menyelesaikan masalah adalah kemampuan individu dalam usahanya mencari jawaban atau jalan keluar terhadap permasalahan yang dimiliki atau dihadapi sehingga diperoleh hasil pemilihan salah satu jawaban dari beberapa alternatif pemecahan yang mengarah pada satu tujuan tertentu. Penyesuaian diri akan lebih berhasil jika disertai dengan kemampuan memilih tindakan yang tepat dan pengendalian diri secara tepat pula, dalam situasi ini individu berusaha memilih tindakan mana yang harus dilakukan. Di samping itu, individu harus mampu mengendalikan dirinya dalam melakukan tindakannya.

\section{Penyesuaian diri negatif}

\section{Reaksi pertahanan}

Ketika responden mengalami kesalahan terhadap pelanggan tekait pemotongan rambut, maka disini responden berusaha menutupi kesalahan yang diperbuat dengan cara mempertahankan dirinya dengan menyalahkan pelanggan atas kesalahan yang dilakukannya. Responden melakukan pembentukan reaksi ini dikarenakan responden tidak ingin disalahkan walaupun hal tersebut memang murni salah dari responden. Sejalan dengan hasil penelitian Sanyata (2009) yang menyatakan mekanisme bertahan sering dipakai untuk menutupi atau menolak realita sebagai bentuk ketidakmampuan individu dalam memandang dirinya secara obyektif, sistem bertahan cenderung muncul secara tidak disadari oleh individu tetapi dapat terlihat melalui refleksi, pikiran, perasaan, dan motif seseorang. Hasil dari temuan di atas sejalan dengan teori penyesuaian diri yang salah, dimana menurut Sunarto \& Hartono (2013) reaksi pertahanan yang dilakukan responden masuk dalam teori proyeksi yaitu melemparkan sebab kegagalan dirinya kepada pihak lain untuk mencari alasan yang dapat diterima. Sebab kegagalan tersebut karena kecerobohan yang dilakukannya, sehingga responden melemparkan kesalahannya. Bentuk pertahan diri yang dilakukan responden dikarenakan responden malu mengatakan perbuatanya tersebut dan hal itu juga dapat berdampak pada pekerjaanya.

\section{Penyesuaian sosial}

Pola yang ditemukan dari seluruh responden, peneliti menemukan bahwa penyesuaian sosial ditunjukkan dalam tiga bentuk:

Relasi di tempat kerja

Individu mampu menciptakan relasi di tempat kerjanya sehingga memiliki sahabat yang bisa diajak bercerita dan juga bertukar pendapat terkait pekerjaan maupun kehidupan sehariharinya. Hasil dari penelitian ini sejalan dengan teori penyesuaian diri Schneiders (1964) yang menyatakan participation adalah melibatkan diri dalam berelasi, setiap individu harus dapat mengembangkan dan memelihara persahabatan. Seseorang yang tidak mampu membangun relasi dengan orang lain dan lebih menutup diri dari relasi sosial akan menghasilkan penyesuaian diri yang buruk. Individu ini tidak memiliki ketertarikan untuk berpartisipasi dengan aktivitas dilingkungannya serta tidak mampu untuk mengekspresikan diri mereka sendiri, sedangkan bentuk penyesuaian akan dikatakan baik apabila individu tersebut mampu menciptakan relasi yang sehat dengan orang lain, mengembangkan persahabatan, berperan aktif dalam kegiatan sosial, serta menghargai nilai-nilai yang berlaku di masyarakat.

Ketika responden telah mendapatkan kenyamanan di tempat kerja yang dikarenakan adanya dukungan dari sahabat atau relasi maka sikap penerimaan terkait pekerjaan pun akan lebih kuat, sehingga responden tidak mengalami kesulitan-kesulitan dan perilaku yang membuatnya tertekan. Sejalan dengan penelitian Asiah (2007) yang menyatakan bahwa orang-orang pada komunitas tersebut memberikan sikap dan tingkah laku yang menurut responden menyenangkan. Sebuah sikap penerimaan yang penuh dengan nuansa kekeluargaan seperti tidak sungkan untuk menolong atau ketika para responden mengalami kesulitan. Demikian pula sebaiknya, jika orangorang tersebut dapat menerima para responden sebagai bagian dari mereka maka tentunya respondentelah menerapkan sikap dan perilaku yang menyenangkan buat mereka sehingga tidak adanya diskriminasi, pengucilan, atau dipandang rendah dari anggota lain.

\section{Sikap tolong menolong}

Terdapat sikap sosial dan kepekaan yang dimiliki responden terhadap masalah dan kesulitan orang lain di sekitarnya. Responden akan menolong sesuai dengan kemampuan yang dimilikinya. Hasil dari penelitian ini sejalan dengan teori penyesuaian diri Schneiders (1964) yaitu bahwa social 
approval adalah minat dan simpati terhadap kesejahteraan orang lain. Hal ini dapat merupakan bentuk penyesuaian diri dimasyarakat, dimana individu dapat peka dengan masalah dan kesulitan orang lain disekelilingnya serta bersedia membantu meringankan masalahnya. Selain itu individu juga harus menunjukan minat terhadap tujuan, harapan dan aspirasi, cara pandang ini juga sesuai dengan tuntutan dalam penyesuaian keagamaan (religious adjustment).

Selain merupakan hal yang sepatutnya dilakukan, pemberian bantuan juga dilakukan untuk menumbuhkan rasa kebersamaan sehingga dapat memecahkan permasalahan yang sedang dihadapi. Menurut House (dalam Smet, 1994) dukungan sosial merupakan hubungan interpersonal yang di dalamnya berisi pemberian bantuan yang melibatkan aspekaspek yang terdiri dari informasi, perhatian emosional, penghargaan dan bantuan instrumental yang diperoleh individu melalui interaksi dengan lingkungan. Masing-masing dukungan tersebut memiliki manfaat bagi si penerima nantinya, sehingga dapat membantu remaja dalam mengatasi masalahnya yaitu mengurangi stress, kecemasan atau berbagai tekanan lainnya. Sikap tolong menolong ini merupakan suatu sikap kepedulian satu sama lainnya agar terciptanya hubungan yang baik.

\section{Aturan di tempat kerja}

Adanya sikap pelanggaran yang responden lakukan di dalam peraturan pekerjaan terkait dengan kedisiplinan. Disiplin kerja pada pegawai sangat dibutuhkan, karena apa yang menjadi tujuan organisasi akan sukar dicapai apa bila tidak ada disiplin kerja. Sesuai pendapat dari Moekizat (2002) disiplin timbul karena adanya command discipline dan self imposed. Command discipline, dalam hal ini sebuah organisasi harus membuat peraturan yang jelas dan memberikan sanksi yang tegas kepada pelaku yang tidak patuh pada peraturan, dengan adanya sanksi yang tegas, maka akan meminimalisir pegawai untuk melakukan tindakan yang melanggar disiplin kerja. Self imposed, atasan harus bisa membantu pegawai untuk menumbuhkan disiplin di dalam diri pegawai dengan cara memberikan teladan yang baik kepada bawahannya, sehingga pegawai akan termotivasi untuk bekerja secara disiplin.

Kondisi yang tercipta pada responden yaitu adanya sikap pelanggaran terkait peraturan seperti terlambat masuk kerja, masalah absen dan juga kesalahan dalam memakai seragam. Perilaku itu tercipta melalui proses binaan melalui keluarga, pendidikan dan pengalaman maka dapat dipahami bahwa disiplin menyatu dalam diri seseorang. Sejalan dengan penelitian Polapa (2014) sikap disiplin diperoleh dari adanya pembinaan yang dimulai dari lingkungan yang paling kecil dan sederhana yaitu keluarga. Disiplin kaitannya dengan pekerjaan adalah ketaatan melaksanakan aturan-aturan yang mewajibkan atau diharapkan oleh suatu organisasi agar setiap tenaga kerja dapat melaksanakan aturan-aturan yang mewajibkan atau diharapkan oleh suatu organisasi agar setiap tenaga kerja dapat melaksakan pekerjaan dengan tertib dan lancar.

Pada pola proses penyesuaian diri dan sosial pada laki-laki yang bekerja di salon, hal yang paling menonjol yaitu lebih pada konteks pekerjaan, lingkungan pekerjaan dan pada pola komunikasi. Banyaknya kemampuan-kemampuan diri yang ingin responden kembangkan sehingga banyak memunculkan suatu kajian terhadap konteks pekerjaan. Terciptanya hubungan harmonis atau kesesuaian antara individu dengan lingkungan kerjanya, dimana hubungan ini bisa dilakukan dengan cara mengembangkan kemampuan, pengetahuan, keterampilan, dan kepribadian individu yang harus sesuai dengan kebutuhan yang diharapkan dan pada lingkungan kerja harus bisa memuaskan kebutuhan pekerjanya. Penyesuaian ini dilakukan oleh ketiga responden, terutama terkait dengan faktor kondisi lingkungan kerja. Ketiga responden pun ratarata dapat menciptakan kesesuaian seperti yang diharapkan oleh responden sendiri maupun kantor tempat mereka bekerja. Kendala yang terjadi selama bekerja tidak terlalu menghalangi penyesuaian kerja responden, baik saat awal bekerja maupun setelah menjalani pekerjaannya.

\section{Perubahan Selama Bekerja di Salon}

Terdapat perubahan yang didapatkan responden dapat dilihat dari segi ekonomi, kemampuan menata rambut dan keterampilan. Menurut Dunette (1976) keterampilan berarti mengembangkan pengetahuan yang didapatkan melalui latihan dan pengalaman dengan melaksanakan beberapa tugas, keterampilan juga dapat membantu menghasilkan suatu yang bernilai dengan lebih cepat. Responden dapat meningkatkan kemampuan menata rambut dan keterampilan dengan cara mengikuti pelatihan berupa seminar dan mencari pengalamanpengalaman terkait menata rambut, sehingga hasil kerja yang di dapatkan saat ini sangat menunjang penghasilannya atau perekonomiannya. Hal tersebut merupakan prestasi kerja bagi responden karena menunjukan kualitas yang baik dalam bekerja. Sejalan dengan penelitian Polak (2012) menunjukkan bahwa keterampilan kerja berpengaruh terhadap prestasi kerja karyawan, sehingga kenaikan maupun penurunan yang terjadi pada keterampilan kerja juga secara parsial akan memengaruhi prestasi kerja karyawan. Selain itu perubahan yang ditunjukan responden yaitu pada perilakunya dimana responden merasa dirinya lebih feminin yang disebabkan karena lingkungan responden yang lebih dominan dengan perempuan.

\section{Kesimpulan}

Kesimpulan yang dapat ditarik dari penelitian yang berjudul penyesuaian diri dan penyesuaian sosial penata rambut lakilaki adalah sebagai berikut: Pertama, pengambilan keputusan bekerja di salon sebagai penata rambut laki-laki karena adanya ketertarikannya terhadap dunia kecantikan, minat dan keterampilan atau kemampuan yang dimilikinya sebagai penata rambut. Kedua, ketika seorang laki-laki memilih pekerjaan sebagai penata rambut terdapat pandangan internal yang lebih kuat berpengaruh dibandingkan pandangan eksternal responden, karena adanya kemampuan responden untuk membentuk pola penguatan di lingkungannya. Baik dalam keluarga maupun masyarakat, sehingga pada proses penyesuaian diri dan penyesuaian sosial dari hasil penelitian ini lebih mengarah pada pekerjaannya yaitu bagaimana meningkatkan kemampuan menata rambut dan keterampilan sehingga tidak lagi berbicara terkait pandangan masyarakat ataupun keraguan yang ada di dirinya. Maka dari itu responden tetap mempertahankan pekerjaannya sebagai penata 
rambut meskipun termasuk ke dalam non conformity gender dan atypicality gender. Ketiga, terdapat perubahan yang dirasakan responden dapat dari segi ekonomi, kemampuan menata rambut, keterampilan, dan juga perubahan penampilan yang berdampak pada perilaku responden yang merasa dirinya lebih feminin yang disebabkan karena lingkungan responden yang lebih dominan dengan perempuan.

Saran untuk responden penelitian dapat menjadikan hasil penelitian ini sebagai bahan evaluasi pribadi untuk mengetahui sejauh mana penyesuaian diri dan sosial yang dilakukan, sehingga dapat mempertimbangkan kekurangan-kekurangan yang dianggap sebagai hal yang belum dirasa cukup. Proses penyesuaian diri dan sosial yang sudah dirasa baik oleh responden dapat dipertahankan agar responden dapat menjalani pekerjaannya lebih baik lagi. Bagi keluarga responden selain motivasi internal atau kepercayaan diri yang menentukan dalam menjalani pekerjaannya, ada baiknya keluarga pun ikut mendukung dengan cara belajar untuk menerima kegemaran yang menjadi minat responden. Keluarga sebaiknya memberikan semangat kepada responden untuk terus mengembangkan usaha, kemampuan menata rambut, meningkatkan keterampilan di bidang salon kecantikan dan ikut membantu mempromosikan profesi yang dijalani responden. Tujuannya agar responden memiliki kualitas dan sukses pada bidang pekerjaan yang dijalaninya saat ini..

Bagi penulis selanjutnya disarankan dapat mencari variasi lain dari penelitian terkait penata rambut laki-laki di salon kecantikan, kemudian dapat menggali lebih dalam hasil wawancara yang dilakukan dan juga bagi peneliti selanjutnya dapat mencari tahu perbedaan antara bekerja sebagai penata rambut di salon kecantikan dengan bekerja di salon pemangkas rambut yang mengkhususkan laki-laki, yang dimana sama-sama merupakan profesi sebagai penata rambut. Saran lain yang dapat diberikan adalah dalam proses penggalian data. Berdasarkan hasil observasi yang dilakukan, keberadaan pelanggan dan karyawan memengaruhi responden dalam memberikan jawaban saat proses wawancara berlangsung, dimana yang menjadikan responden tidak fokus dengan pertanyaan yang diajukan peneliti dan sebaiknya pemilihan lokasi dan waktu wawancara menjadi hal yang penting untuk dipertimbangkan.

\section{DAFTAR PUSTAKA}

Agustiani, H. (2009). Psikologi perkembangan: pendekatan ekologi kaitannya dengan konsep diri dan penyesuaian diri pada remaja. Bandung: Refika Aditama.

Alwi, S. (2001). Manajemen sumber daya manusia: strategi keunggulan kompetensi. Yogyakarta: BPFE.

American Psychological Association. (2015). APA dictionary of psychology (2nd). Washington, DC: Author.

Anthony R. (1992). Rahasia membangun kepercayaan diri. Jakarta: Bina Rupa Aksara.

Asiah, N. (2007). Penyesuaian diri wanita pekerja pada bidang pekerjaan yang di dominasi laki-laki. Skripsi. Jakarta: Fakultas Psikologi Universitas Islam Negeri Syarif Hidayatullah. Diunduh dari http://repository.uinjkt.ac.id/dspace/bitstream/123456789/
24389/1/NUR\%20ASIAH-PSI.pdf. Diakses tanggal 20 Juni 2014.

Atwater, E. (1983). Psychology of adjusment: "personal growth in changing world" $\left(2^{\text {nd }}\right.$ edition $)$. New Jersey: Prentice Hall.

Azwar, S. (1998). Metode penelitian. Edisi I. Pustaka Pelajar: Jakarta.

Baron, P. A \& Byrne, C. (1974). Sexuality and the dual-earner couple: multiple roles and sexual functioning. Journal of Family Psychology. 12(3).

Bem, S. L. (1981). Gender schema theory: a cognitive account of sex typing. Psychological Review.

Burr, V. (1998). Gender and social psychology. USA and Canada

Carnegie, D. (2000). Berbicara efektif: teknik modern untuk komunikasi yang dinamis. Jakarta: Pustaka Delapratasa.

Colonne, S. \& Eliana, R. (2009). Gambaran tipe-tipe konflik intrapersonal waria ditinjau dari identitas gender. Jurnal Ps. Psikologi Fakultas Kedokteran Universitas Sumatera Utara. 2 (1). Diunduh dari http://repository.usu.ac.id/handle/123456789/15717. Diakses tanggal 2 juni 2009.

Davidoff, L.L. (1988). Psikologi suatu pengantar. Edisi Kedua. Jakarta: Erlangga.

Davidson, G. Neale \& Kring. (2006). Psikologi abnormal. Edisi ke9. Jakarta: Rajawali pers.

DePaul, J. (2009). School belonging and social support: identifying moderators of the relationship between gender typicality and self-esteem. Boston College University Libraries.

Depdikbud. (2005). Kamus besar bahasa indonesia (Edisi ke-3). Jakarta: Balai Pustaka.

Dunette, Peter F. (1976). Pengertian keterampilan (online). Diunduh dari

http://Jurnal.ekonomi.Kompasiana.com/manajemen/2011/ 05/26/penelitian-dan-pengembangan-sumber-dayamanusia.html. Diakses tanggal 17 September 2015.

Effendy, O. (1994). Ilmu Komunikasi: Teori dan Praktek. Bandung: Remaja Rosdakarya.

Enung, F. (2008). Psikologi perkembangan peserta didik. Bandung: CV Pustaka Setia.

Fakih, M. (1997). Analisis gender dan tranformasi sosial. Yogyakarta: Pustaka Pelajar.

Fakih, M. (2008). Kekerasan gender dalam pembangunan, dalam ahmad suaedy(ed), kekerasan dalam perspektif pesantren. Jakarta: Garrsindo.

Ferdiyansyah. (2013). Gambaran kebahagiaan pada waria yang berprofesi sebagai pengamen jalanan di kota yogyakarta. Thesis. Yogyakarta: Program Studi Psikologi Fakultas Ilmu Sosial Dan Humaniora Universitas Islam Negeri Sunan Kalijaga Yogyakarta. Diunduh dari http://digilib.uin-suka.ac.id/id/eprint/12422. Diakses tanggal 8 Mei 2014.

Girsang. (2014). Faktor-faktor pendorong dan penghambat pengusaha wanita dalam mendirikan usaha salon dijalan jamin ginting. Program Studi Diploma Iii Kesekretariatan Fakultas Ekonomi Dan Bisnis Universitas Sumatera Utara Medan. Diunduh dari http://repository.usu.ac.id/handle/123456789/46037. Diakses tanggal 4 Mei 2015.

Gunarsa \& Gunarsa. (2004). Psikologi perkembangan anak dan remaja. Jakarta: Gunung Mulia.

Hariyanti \& Primawesri. (2011). Pengaruh komunikasi dan motivasi terhadap kinerja pesawat dengan komitmen organisasi sebagai variabel moderating. Thesis. STIE AUB Surakarta dan Universitas Setia Budi Surakarta.

Herdiansyah, H. (2013). Metodologi penelitian kualitatif untuk ilmuilmu sosial. Jakarta: Salemba Humanika.

Herdiansyah, H. (2015). Metodologi Penelitian Kualitatif untuk Ilmu Psikologi. Jakarta: Salemba Humanika 


\section{I.A.A.W VIRGADEWI K \& M.D LESTARI}

Hurlock, E. B. (1980). Psikologi perkembangan suatu pendekatan sepanjang rentang kehidupan. Edisi 5. Jakarta: Erlangga

Iswari, H. P. (2014). Representasi identitas waria dalam kostum waria pada film madame $x$. Thesis. Surabaya: Universitas $\begin{array}{llll}\text { Airlangga. } & 3(3) . & \text { Diunduh }\end{array}$ http://repository.unair.ac.id/id/eprint/15814. Diakses tanggal 25 Agustus 2016.

Lazarus \& Folkman. (1984). Stress appraisal and coping. New York: Springer Publishing Company

Maccoby, E.E. \& Jacklin, C.N. (1974). The psychology of sex differences. Stanford: Stanford University Press.

Marshall, C. \& Rossman, G.B. (2006). Designing qualitative research. Fourth Edition. London: Sage Publication Ltd.

Moekizat. (2002). Manajemen tenaga kerja dan hubungan kerja. Bandung: CV Pionir Jaya.

Moleong, J.L.(2014). Metode penelitian kualitatif. Bandung: PT Remaja Rosdakarya.

Notoatmodjo, S. (2003). Pendidikan dan perilaku kesehatan. Rineka Cipta: Jakarta.

(1997). Ilmu kesehatan masyarakat prinsip-prinsip dasar. Jakarta: Rineka Cipta.

(1993). Pengantar pendidikan dan ilmu perilaku kesehatan. Andi Offset. Yogyakarta.

Patterson, M. M. (2012). Self-perceived gender typicality, gendertyped attributes, and gender stereotype endorsement in elementary-school-aged children. Department Of Psychology \& Research In Education, University of Kansas, Lawrence, KS, USA. Diunduh dari http:/hdl.handle.net/1808/11799. Diakses tanggal 27 Juli 2012.

Poerwadarminta, W. (1982). Kamus umum bahasa indonesia. Jakarta. Balai Pustaka

Poerwandari, E. Kristi (2001). Pendekatan kualitatif untuk penelitian perilaku manusia. Jakarta: Lembaga Pengembangan Sarana Pengukuran dan Pendidikan Psikologi (LPSP3) Universitas Indonesia.

Polak, Yanti. S. (2012). Pengaruh tingkat penddidikan, keterampilan kerja, dan sikap kerja terhadap prestasi kerja karyawan pt bank negara indonesia (persero) tbk cabang makassar. Skripsi. Tidak diterbitkan. Makassar: Universitas Hasanuddin Makassar.

Polapa. (2014). Pengaruh disiplin kerja terhadap kinerja pegawai pada bagian administrasi pemerintahan umum sekretariat daerah kota gorontalo. Other Thesis. Universitas Negeri Gorontalo. Diunduh dari http://eprints.ung.ac.id/id/eprint/3630. Diakses tanggal 19 Februari 2014.

Prasetyowati. (2010). Pola relasi gender dalam keluarga buruh perempuan. Surakarta: Fakultas Keguruan Dan Ilmu Pendidikan Universitas Sebelas Maret. Diunduh dari https://eprints.uns.ac.id/id/eprint/4099. Diakses tanggal 14 Juli 2013.

Qomariyah, N. \& Widyarini. (2006). Penyesuaian diri wanita yang bekerja sebagai pemecah batu di tepi sungai ciapus, bogor. Jurnal Penelitian Fakultas Psikologi Universitas Gunadarma. 2(11). Diunduh dari http://library.gunadarma.ac.id/repository/view/319674/pe nyesuaian-diri-wanita-yang-bekerja-di-bidang-pekerjaanyang-bersifat-maskulin.html.

Rahayu, R. (2011). Konsep dan aplikasi penelitian gender. Bandung: Muara Indah

Ratnaningsih, N. (2013). Pengaruh motivasi kerja dan pengalaman kerja terhadap produktivitas kerja karyawan pada pt. taspen (persero) kantor cabang yogyakarta. Thesis. Fakultas Ekonomi Universitas Negeri Yogyakarta. Diunduh dari http://eprints.uny.ac.id/id/eprint/17817. Diakses tanggal 30 April 2015.
Rivai, V. (2004). Kepemimpinan dan perilaku organisasi, Edisi Kedua. Jakarta: PT. Raja Grafindo Persada.

Rostamailis, Hayatunnufus \& Merita, Y. (2008). Tata kecantikan rambut jilid 1. Jakarta: Departemen Pendidikan Nasional.

Rudhaliawan, V. M. (2013). Pengaruh pelatihan terhadap kemampuan kerja dan kinerja karyawan. (Studi pada karyawan pt. telkom indonesia, tbk kandatel malang). Moehammad Soe'oed Hakam. Fakultas Ilmu Administrasi Universitas Brawijaya Malang. 4(2). Diunduh dari http://administrasibisnis.studentjournal.ub.ac.id/index.php /jab/article/view/180.

Ruhghea, S. M \& Risana. R. (2014). Studi kualitatif kepuasan hidup pria transgender (waria) di banda aceh. Jurnal Psikologi Fakultas Kedokteran Universitas Syiah Kuala. 1(13). Diunduh dari http://ejournal.undip.ac.id/index.php/psikologi/article/vie w/8062. Diakses tanggal 13 Januari 2015.

Santoso, S. (2010). Teori-teori psikologi sosial. Yogyakarta: Reflika Aditama.

Santrock, John W. (2002). Life-span development: perkembangan masa hidup. Edisi 5. Jakarta: Erlangga.

Santrock, J. W. (2007). Remaja. Jakarta: Erlangga.

Sanyata, S. (2009). Mekanisme dan taktik bertahan: penolakan realita dalam konseling. Jurnal Paradigma. Jurusan Psikologi Pendidikan dan Bimbingan Fakultas Ilmu Pendidikan Universitas Negeri Yogyakarta. Diunduh dari http://staffnew.uny.ac.id/upload/132297302/penelitian/B. 1i.Artikel+Ilmiah-Mekanisme+dan+Taktik+Bertahan.pdf. Diakses tanggal 8 Juli 2009.

Schneiders, A. (1964). Personal adjustment and mental health. New York: Holt, Rineharr, And Wisnton.

Sehfudin, A. (2011). Pengaruh gaya kepemimpinan, komunikasi organisasi dan motivasi kerja terhadap kinerja karyawan. Fakultas Ekonomi Universitas Diponegoro Semarang. Diunduh Dari Http://Eprints.Undip.Ac.Id/26964/. Diakses Tanggal 21 April 2011.

Simamora, H. (1995). Manajement sumber daya manusia. Edisi Kesatu, Cetakan Pertama. Yogyakarta: Badan Penerbit STIE.

Situmorang, N. Z. (2011). Gaya kepemimpinan perempuan. Jawa Barat: Fakultas Psikologi Universitas Gunadarma.

Smet, B. (1994). Psikologi kesehatan. Jakarta: PT Grasindo.

Solso, R.L. (2008). Psikologi kognitif. Edisi Kedelapan. Jakarta: Erlangga

Strong \& De Vault. (1989). The marriage and family experience (4th ed). St. Paul: West Pub.co

Suharnan. (2005). Psikologi kognitif. Surabaya: Srikandi

Sugiyono. (2014). Metode penelitian kombinasi (mix methods). Bandung: Alfabeta.

Sukmana, G. M. (2013). Pengaruh tingkat pendidikan, pengalaman kerja dan pemberian insentif kerja terhadap produktivitas tenaga kerja (kasus pada cv. yugatama prima mandiri kab. Jember). Jurnal Ilmiah. Fakultas Ekonomi dan Bisnis. 1(2). Diunduh dari http://jimfeb.ub.ac.id/index.php/jimfeb/article/view/522.

Suma'mur, P.K. (2014). Higiene perusahaan dan kesehatan kerja (hiperkes). Jakarta: CV Sagung Seto.

Sunarto \& Hartono. (2013). Perkembangan peserta didik. Jakarta: Rineka Cipta

Virgadewi. (2015). Tanggapan dan pandangan laki-laki terkait profesi feminin. (Naskah Tidak Dipublikasikan). Fakultas Kedokteran, Universitas Udayana, Bali.

Taylor \& Francis. (2012). At the cutting edge of the city: male migrant hairdresser in shanghai. Journal Asian Studies Review. Vol 36. Diunduh dari 
http://dx.doi.org/10.1080/10357823.2012.712945.

Diakses September 2012.

Taylor, S. E. Peplau, L. A., \& Sears, D. O. (2009). Psikologi sosial. Jakarta: Kencana Prenada Media Group.

Tulus, A. M. 1993. Manajemen sumber daya manusia. Jakarta: Gramedia.

Wardani, E.S. (2009). Pengaruh kompensasi, keahlian dan motivasi kerja terhadap prestasi kerja karyawan pada pt. Pembangkitan jawa bali unit pembangkitan muara tawar. Fakultas Ekonomi, Jurusan Manajemen Universitas Gunadarma. Diunduh dari http://www.gunadarma.ac.id/library/articles/graduate/eco nomy/2009/Artikel_10205401.pdf. Diakses tanggal 20 Oktober 2010

Wathani, F. (2009). Perbedaan kecenderungan pembelian impulsif produk pakaian ditinjau dari peran gender. Skripsi. Fakultas Psikologi Universitas Sumatera Utara.

Wright, T.A. (1997). Time revisited in organizational behavior. Journal Of Organizational Behavior. 3 (18). Diunduh dari http://www.jstor.org/stable/3100140. Diakses tanggal 4 Desember 1998.

Wulandari, T. (2012). Faktor-faktor yang melatarbelakangi laki-laki berprofesi sebagai perawat. Thesis. Program Studi Pendidikan Sosiologi Jurusan Pendidikan Sejarah Fakultas Ilmu Sosial Universitas Negeri Yogyakarta. Diunduh dari http://eprints.uny.ac.id/id/eprint/24800. Diakses tanggal 13 Agustus 2015.

Yakub, Gunawan \& Halim, J. (2015). Pengaruh kemampuan komunikasi dan kecerdasan emosional terhadap kinerja karyawan pada pt. Perkebunan nusantara i (persero) aceh. Jurnal Ilmiah Saintikom. Program Studi Manajemen, STIE Institut Teknologi Manajemen Internasional. 3(14). Diunduh dari https://lppm.trigunadharma.ac.id/public/fileJurnal/hpGN.

Yulianingsih, Y. (2012). Strategi coping pada remaja pasca putus cinta. Fakultas Psikologi Universitas Muhammadiyah Surakarta. Diunduh dari http://eprints.ums.ac.id/20313/16/11._NASKAH_PUBLI KASI.pdf. Diakses tgl 28 September 2012.

Yvonne, S. (2014). Etos kerja pegawai etnis tionghoa di lima perusahaan keuangan kota surabaya. Student E-Journal Of Chinese Departement. Program Studi Sastra Tionghoa, Fakultas Sastra, Universitas Kristen Petra Surabaya. 1(2). Diunduh dari http://studentjournal.petra.ac.id/index.php/sastrationghoa/article/view/2100. Diakses tanggal 10 Juni 2014.

Zamroni, E. (2016). Urgensi career decision making skills dalam penentuan arah peminatan peserta didik. Jurnal Konseling. Program Studi Bimbingan Dan Konseling FKIP Universitas Muria Kudus. 2(2). Diunduh dari http://dx.doi.org/10.24176/jkg.v2i2.700. 


\section{LAMPIRAN}

Tabel 1

Pandangan Laki-Laki Terhadap Pekerja Laki-Laki di Sebuah Salon Kecantikan

\begin{tabular}{lll}
\hline No & Pendapat & Frekuensi \\
\hline 1. & Biasa saja & 7 \\
\hline 2. & Pekerjaan halal \& legal & 14 \\
\hline 3. & $\begin{array}{l}\text { Memiliki kepribadian } \\
\text { ganda }\end{array}$ & 4 \\
\hline 4. & Tuntutan ekonomi & 2 \\
\hline 5. & $\begin{array}{l}\text { Kepribadian lemah } \\
\text { lembut }\end{array}$ & 2 \\
\hline 6 & Kegemaran & 1 \\
\hline
\end{tabular}




\section{Bagan 1}

Skema Penelitian

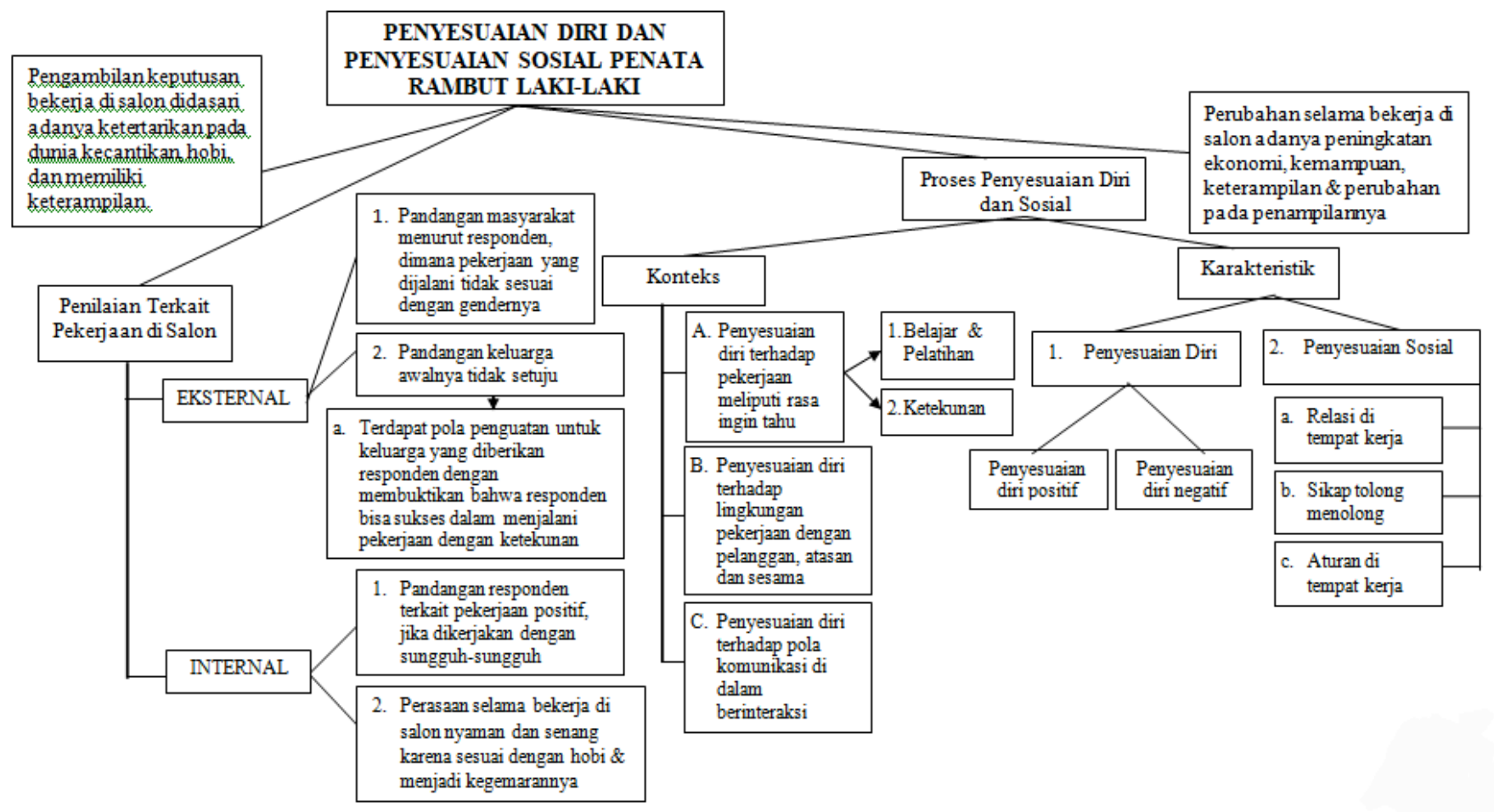

